\title{
CERVICAL ANKYLOSIS WITH ACUTE SPINAL CORD INJURY ${ }^{1}$
}

\author{
By J. S. Young, M.D., D. J. E. Cheshire, M.B., B.S.(Lond.), D.Phys.Med.(Eng.), \\ D.P.R.M.(Aust.), J. A. Pierce, M.D. and J. M. Vivian, M.D. \\ Southwest Regional System for Treatment of Spinal Injury, Good Samaritan Hospital, \\ I033 East McDowell Road, Phoenix, Arizona 85006, U.S.A.
}

Abstract. Twenty-three cases of acute spinal cord injury in persons with cervical ankylosis are presented. Certain characteristics of major sub-groups are described: ankylosing spondylitis $(N=8)$, degenerative spondylosis $(N=9)$ and congenital fusion (congenital non-segmentation) $(N=6)$. The ankylosing spondylitic group presented a grim prognosis for survival (death rate 50 per cent within 60 days) and for loss of neurological function. Five out of eight cases had permanent neurological loss subsequent to their injuries.

Both the ankylosing spondylitic and degenerative spondylotic groups presented problems in diagnosis and medical management. The basic principle is immobilisation of the fracture and mobilisation of the patient. The halo is the technique of choice for fracture immobilisation. An integrated intensive respiratory management programme is essential. Patients with ankylosed spines, particularly those with ankylosing spondylitis, should be educated in simple measures to prevent fracture of their spines.

\section{Introduction}

CERviCAL ankylosis is characterised by an inflexibility of the cervical spine. This predisposes the ankylosed spine to fracture with resultant damage to the spinal cord. The forces required to do this may be minor, resulting in a high incidence of spinal cord impairment as a result of low velocity injuries. The spinal rigidity and compromise of the cross-sectional area of the spinal canal may cause damage to the spinal cord even without fracture.

Quoting Heathfield (1973, p. 2): 'Sudden death in rheumatoid arthritis from dislocation of the cervical spine has been known since the days of Sir Charles Bell (I824)'. The first case of spinal cord injury resulting from fracture of an ankylosed spine was reported by Abdi (1904). Stiasny (1933) reported the first case of cervical spinal cord injury associated with ankylosing spondylitis and made three important observations: delayed onset and diagnosis, the absence of major neurological change and a rapid bony consolidation. Subsequently, a number of cases have been reported by authors such as Bergmann (I949), Cheshire (1969), Hollin et al. (1965), Guttmann (1966), Symonds (1953), Hughes and Brownell (1963), Woodruff and Dewing (1963), Osgood et al. (I973, I975), Rand and Stern (I96I).

Most of the papers presented in the literature on cervical ankylosis have pertained to ankylosing spondylitis. It is the purpose of this paper to report 23 cases of spinal cord injury associated with cervical ankylosis, examining the characteristics of three major sub-groups: ankylosing spondylitis, degenerative spondylosis and congenital fusion (non-segmentation), reporting results of treatment, and making certain observations and recommendations pertaining to their medical management. The cases reported were treated in the Southwest Regional System for Treatment of Spinal Injury, established in 1970 in Phoenix, Arizona. Treat-

1 This project was supported in part by U.S. Department of Health, Education and Welfare, Rehabilitation Services Administration Grant No. 13-P-55258/9.

I $5 / 2-C$ 
ment was provided at Barrow Neurological Institute, St Joseph's Hospital and Medical Center, and/or the Spinal Cord Injury Service of Good Samaritan Hospital. The authors participated in a primary or consulting role in the management of all cases.

\section{Patients Studied}

One hundred and seventy-four cases of cervical spinal cord injury were treated in the Southwest Regional System between I June 1970, and 3I December 1975. Of these, I6 cases had penetrating wounds and have been removed from this study in that they are not germane to the subject. The remaining 158 cases comprise the sample population to be reported. Of this group there were 23 cases with ankylosed spines. Table I describes the distribution by diagnostic group.

Calin and Fries (1975) estimate the incidence of ankylosing spondylitis to be I. 4 per cent, based on a control study of supposedly healthy individuals with histocompatibility antigen-HL-A W27. The incidence of co-existing ankylosing spondylitis and spinal cord injury in our study appears to be at least four times the incidence of ankylosing spondylitis in the normal population. Meszaros (1965) reported four cases with congenital synostosis in 74 cervical spinal cord injuries. This incidence $(5.4$ per cent) is slightly higher than our 3.8 per cent. The normal incidence reported by Reinhold et al. (1959) (quoted by Meszaros) was 0.9 per cent. Shands and Bundens (1956) reported an incidence of 0.4 per cent congenital fusion in a series of 700 children. Brown et al. (1964) report an incidence of $0 \cdot 7 \mathrm{I}$ per cent congenital fusion. Thus, it appears the incidence of co-existing fusion in spinal cord injury is almost eight times greater than expected in the normal population. Brown et al. (1964) report an incidence of acquired spinal fusion of 4.65 per cent. This suggests that the incidence of degenerative spondylosis and spinal cord injury in our study is comparable to the incidence of spondylosis in the normal population.

\section{Methods and Materials}

Some characteristics of the sub-groups can be defined by demographic data such as age, sex and aetiology (Table II). The sub-groups ankylosing spondylitis and degenerative spondylosis have a significantly higher mean age than the total cervical group. This is consistent with the observation that the vertebral spines of these two groups become more brittle and osteoporotic with age. The congenital fusion group has no apparent difference in mean age from the total cervical group. As would be expected, ankylosing spondylitis occurred predominantly in

\section{TABLE I}

Distribution of sample population by diagnosis

\begin{tabular}{lrr}
\hline \multicolumn{1}{c}{ Diagnosis } & $N$ & Per cent \\
\cline { 2 - 3 } Total cervical cases & I 58 & I $00 \cdot 0$ \\
Ankylosis & 23 & $14 \cdot 6$ \\
Ankylosing spondylitis & 8 & $5 \cdot 0$ \\
Degenerative spondylosis & 9 & $5 \cdot 7$ \\
Congentital fusion & 6 & $3 \cdot 8$ \\
\hline
\end{tabular}


TABLE II

Demographic data

\begin{tabular}{|c|c|c|c|c|c|c|c|}
\hline & \multirow[t]{2}{*}{$N$} & \multirow{2}{*}{$\underset{(\mathrm{yr})}{\text { Mean age }}$} & \multicolumn{2}{|c|}{$\operatorname{Sex}(\%)$} & \multicolumn{3}{|c|}{ Aetiology $(\%)$} \\
\hline & & & Male & Female & Automobiles & Falls & Other \\
\hline $\begin{array}{l}\text { Total cervical cases } \\
\text { Ankylosing }\end{array}$ & I 58 & 36 & 82 & I 8 & 52 & 20 & 28 \\
\hline $\begin{array}{r}\text { spondylitis } \\
\text { Degenerative }\end{array}$ & 8 & 59 & 100 & 0 & I 2 & 88 & 0 \\
\hline $\begin{array}{l}\text { spondylosis } \\
\text { Congenital fusion }\end{array}$ & $\begin{array}{l}9 \\
6\end{array}$ & $\begin{array}{l}64 \\
39\end{array}$ & $\begin{array}{l}77 \\
74\end{array}$ & $\begin{array}{l}23 \\
25\end{array}$ & $\begin{array}{l}66 \\
66\end{array}$ & $\begin{array}{l}22 \\
16\end{array}$ & $\begin{array}{l}\mathrm{I} 2 \\
\mathrm{I} 8\end{array}$ \\
\hline
\end{tabular}

males. The other sub-groups demonstrated a slightly higher percentage of females than experienced in the total group. The most striking, unique variance was in the aetiology of ankylosing spondylitic injuries. Eighty-eight per cent were caused by falls. Further, most of these were low velocity falls, i.e., striking the head against a table, falling out of bed, falling in the bathroom, etc. This important clinical observation has been made by authors such as Bergmann (I949), Abdi (1904), Good (1967), Guttmann (1966), Rand and Stern (1961), Osgood et al. (1973, 1975) and Woodruff and Dewing (1963). These observations emphasise the need for a high degree of diagnostic suspicion in cases of even minor head and neck injuries involving a spondylitic.

\section{Mechanism of Injury}

Extension is the primary mechanism of spinal injury occurring in persons with ankylosing spondylitis and degenerative spondylosis (Table III). Our experience is consistent with the observation of authors who have previously stressed this important clinical point. They include Guttmann (I966), Burke (I97I), Cheshire (1969), Taylor (1953), Brain and Wilkinson (1967), Symonds (1953), Osgood et al. (1973, I975), Rand and Stern (196I), Schneider et al. (1954), and Woodruff and Dewing (1963). All eight of our cases of ankylosing spondylitis had historical or radiographic evidence of an extension mechanism. Eight out of nine cases with degenerative spondylosis resulted from extension. One occurred as a result of axial loading. Of the six cases with congenital fusion, three injuries were caused by

\section{TABLE III}

Mechanism of injury distribution

\begin{tabular}{lcccc}
\hline \multicolumn{1}{c}{ Diagnosis } & $N$ & Extension & Flexion & $\begin{array}{c}\text { Axial } \\
\text { loading }\end{array}$ \\
\hline Ankylosing spondylitis & 8 & 8 & 0 & 0 \\
Degenerative spondylosis & 9 & 8 & 0 & $\mathrm{I}$ \\
Congenital fusion & 6 & 3 & 3 & 0 \\
\hline
\end{tabular}


flexion and three by extension. This distribution is probably no different than that which may be expected in a random cervical spinal cord injured population.

\section{Fracture Instability at 12 Weeks}

Many authors have reported the phenomenon of rapid bony consolidation of injuries to the ankylosed cervical spine. They include Ackerman (1972), Bergmann (1949), Cheshire (1969), Good (1967), Grisolia et al. (1967) and Rand and Stern (I96I). Our experience (Table IV) substantiates their observations. Removing the cases which were not applicable, seven of our cases became stable within I 2 weeks. Three remained unstable. Stability is defined as, 'The absence of any abnormal mobility between any pair of vertebrae, with or without pain or other clinical manifestations, when lateral X-rays of the cervical spine are taken in flexion and extension' (Cheshire, I969). It is an interesting observation that, of the three cases demonstrating instability, one had a laminectomy, one had an anterior body fusion and one had a posterior fusion. None of those that became stable had operative intervention. The high incidence of spinal cord injury in ankylosis without demonstrable fracture, as shown in Table IV, is consistent with previous reports by a number of authors (Cheshire, I969; Payne \& Spillane, I957; Brain \& Wilkinson, 1967; Nurick, I972; Taylor \& Blackwood, I948; Woodruff \& Dewing, 1963).

\section{Neurological Preservation}

The ratio of complete/incomplete lesions in the ankylotic group is essentially the same as the ratio of the complete/incomplete lesions in our total population. Our experience is consistent with that reported by Burke (I97I). It reflects a less favourable prognosis than reported by Rand and Stern (I96I), who summarised 2I cases from the literature finding six complete, I I incomplete and four who had no significant neurological deficit. Table $\mathrm{V}$ describes the distribution of neurological syndromes in our 23 cases. As would be expected, in that these are predominantly extension injuries, the most common syndrome was central cord (Schneider et al., I954).

\section{TABLE IV}

Fracture stability at $\mathrm{I} 2$ weeks

\begin{tabular}{lrccccc}
\hline \multicolumn{1}{c}{ Diagnosis } & $N$ & Stable & Unstable & \multicolumn{2}{c}{ Not applicable } \\
\cline { 5 - 7 } & & & & No fracture & Dead Unknown \\
\hline Ankylosing spondylitis & 8 & 3 & $\mathrm{I}^{\star}$ & 0 & 3 & $\mathrm{I}$ \\
Degenerative spondylosis & 9 & 4 & 0 & 3 & 2 & 0 \\
Congenital fusion & 6 & $\mathrm{I}$ & $2 \dagger$ & $2^{\star}$ & $\mathrm{I}$ & 0 \\
$\quad$ & 23 & 7 & 3 & $\mathrm{I} 3$ & 6 & $\mathrm{I}$ \\
\hline
\end{tabular}

* Laminectomy.

$\dagger$ Anterior body fusion; posterior fusion. 


\section{TABLE V}

Neurological syndrome

\begin{tabular}{|c|c|c|c|c|c|c|}
\hline Diagnosis & $N$ & Complete & $\begin{array}{c}\text { Central } \\
\text { cord }\end{array}$ & $\begin{array}{l}\text { Anterior } \\
\text { cord }\end{array}$ & $\begin{array}{l}\text { Brown } \\
\text { sequard }\end{array}$ & Transitory \\
\hline Ankylosing spondylitis & 8 & 5 & 2 & o & 0 & I \\
\hline Degenerative spondylosis & 9 & 2 & 4 & I & I & I \\
\hline Congenital fusion & 6 & 4 & 0 & 2 & o & o \\
\hline Total & 23 & I I & 6 & 3 & I & 2 \\
\hline
\end{tabular}

\section{Deaths}

Ankylosing spondylitis and degenerative spondylosis share a grim prognosis for potential fatality. This is probably related to their common characteristic of representing a more aged population. It appears that ankylosing spondylitis is especially treacherous. Woodruff and Dewing (1963) report a 50 per cent death rate in ankylosing spondylitis. The death rate within 60 days of injury of all our cervical cases was 13.3 per cent. The death rates for the same period for ankylosing spondylitis, degenerative spondylosis and congenital fusion were 50 per cent, 22.2 per cent and I6.6 per cent respectively (Table VI). More complete information pertaining to our fatal cases is presented in Tables VII and VIII. Summarising, these cases reflect an older age group with complete or severe injuries dying

TABLE VI

Death rate

\begin{tabular}{lrc}
\hline \multicolumn{1}{c}{ Diagnosis } & \multicolumn{1}{c}{$N$} & Per cent \\
\hline Total cervical cases & I 58 & I3.3 \\
Ankylosis & 23 & $30 \cdot 4$ \\
Ankylosing spondylitis & 8 & $50 \cdot 0$ \\
Degenerative spondylosis & 9 & $22 \cdot 2$ \\
Congenital fusion & 6 & 16.6 \\
\hline
\end{tabular}

\section{TABLE VII}

Deaths within 60 days from onset

\begin{tabular}{lccccc}
\hline Diagnosis & $N$ & Deaths & $\begin{array}{c}\text { Average } \\
\text { age }\end{array}$ & $\begin{array}{c}\text { Average days } \\
\text { from onset to death }\end{array}$ \\
\hline Ankylosing spondylitis & 8 & 3 & & 59 & 30 \\
Degenerative spondylosis & 9 & 2 & & 63 & 20 \\
Congenital fusion & 6 & I & & 48 & 5 \\
$\quad$ Total & 23 & 6 & 56 & 2 I \\
\hline
\end{tabular}

Cause of death in all cases was cardio-respiratory complications. 
TABLE VIII

Deaths $(N=6)$

\begin{tabular}{ccccccl}
\hline Patient & Age & Aetiology & $\begin{array}{c}\text { Days' } \\
\text { survival }\end{array}$ & $\begin{array}{c}\text { Neurological } \\
\text { level }\end{array}$ & $\begin{array}{c}\text { Neurological } \\
\text { syndrome }\end{array}$ & $\begin{array}{c}\text { Neurological } \\
\text { loss }\end{array}$ \\
\hline I & 58 & Auto & I 8 & C4 & Complete & Complete \\
2 & 28 & Fall & 43 & C6 & Complete & Complete \\
3 & 76 & Fall & 7 & C7 & Complete & Complete \\
4 & 58 & Fall & I5 & C5 & Central & Motor (-) \\
5 & 67 & Fall & 43 & C6 & Central & Motor (+) \\
6 & 87 & Fall & I7 & C7 & Transitory & Normal \\
\hline
\end{tabular}

rather late in the post-injury course. All of our cases died primarily of cardiopulmonary complications.

\section{Neurological Change}

The uniquely grim prognosis for the ankylosing spondylitic group is vividly portrayed by the neurological changes experienced subsequent to injury. Of the 23 cases in the total ankylotic group, 15 remained neurologically unchanged, three had improvement and five had neurological loss (Tables IX and X). All five of the cases which had neurological loss were in the spondylitic group. Two of these went from a normal motor and sensory presentation to a complete spinal cord injury. Similar horrifying case histories have been documented in the literature.

\section{Clinical Management-Diagnosis}

The experience gained from this series of cases compels us to join with other authors in stressing the need for a high index of diagnostic suspicion in instances of even minor head and neck trauma in persons with ankylosed spines, particularly those who have ankylosing spondylitis (Grisolia et al., I967; Hansen et al., 1967; Woodruff \& Dewing, 1963). Many of our cases and the cases reported by others have occurred as a result of minor injuries, particularly falls. Frequently, there is no neurological deficit following the injury. Subsequently, minor or major spinal cord injury is acquired. Our data support the opinion of others that cord damage is unrelated to the extent of the fracture displacement (Bergmann, 1949; Guttmann, 1966; Woodruff \& Dewing, I963; Taylor, 1951). One of our cases had complete

\section{TABLE IX}

Neurological change-onset to discharge

\begin{tabular}{lrccc}
\hline \multicolumn{1}{c}{ Diagnosis } & $N$ & No change & Improvement & Loss \\
\hline Ankylosing spondylitis & 8 & 2 & I & 5 \\
Degenerative spondylosis & 9 & 8 & I & 0 \\
Congenital fusion & 6 & 5 & I & 0 \\
$\quad$ Total & 23 & I5 & 3 & 5 \\
\hline
\end{tabular}


TABLE X

Neurological change-onset to discharge

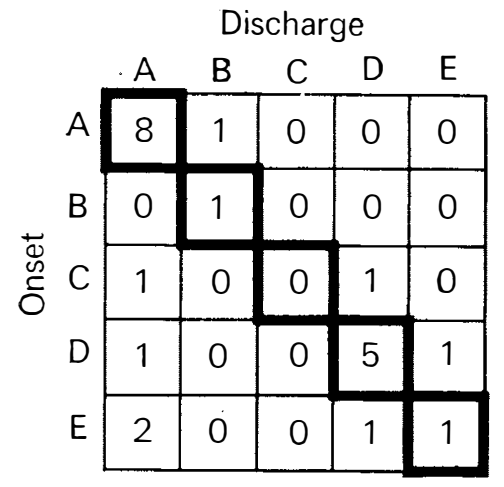

Frankel gRades
A - Complete
B - Preservation - sensory only
C - Preservation - motor useless
D - Preservation - motor useful
E - Normal-motor and sensory

displacement of the vertebral column with no permanent neurological dysfunction. On the other hand, we have observed complete functional transection of the spinal cord without damage to the spinal column. The need for good diagnostic X-rays, including swimmer views and tomography if necessary, is obvious. We agree with Northfield and Osmond-Clarke (1967) that, at times, the instability is difficult to demonstrate. We concur that, in some instances, careful flexion and extension films under radiological control are necessary to demonstrate the instability. Osgood et al (1975) and Lieberg et al. (1975) warn us of the potential existence of multiple fractures. We have one such case in our sample. To add to our anxiety, Farhat et al. (1973) report three cases of rare extradural haematoma occurring in patients with ankylosing spondylitis. These cases had rapid progression of neurological deficit.

\section{Management Problems}

Almost all of the authors who have reported their experience with cervical ankylosis, particularly ankylosing spondylitis, have emphasised that this group of patients have characteristics which make them extremely difficult to manage. Our experience renders us in complete agreement. Fractures in this group of patients may be extremely unstable. Reduction of the fracture is difficult, if not at times impossible. If achieved, redislocation may easily occur. Good fracture immobilisation is mandatory. However, this presents another problem. These cases are primarily of an older age group. Prolonged bed rest is an open invitation for the development of serious medical problems, particularly involving the cardiopulmonary, genito-urinary and integumental systems. Internal fixation is hazardous in that these patients are poor surgical risks. Internal fixation is prone to failure due to the marked osteoporosis. Manipulation of the fracture during 
anaesthesia is a distinct hazard. The high death rate and appalling loss of neurological function subsequent to the injury experienced in our series and the experiences reported by others substantiate that this group of spinal cord injured persons present unique management problems.

\section{Principles of Management}

The authors share with Osgood et al. (1973, I975) and Rand and Stern (196I) a number of important management principles. As previously stated, we wish to re-emphasise the need to maintain a high index of diagnostic suspicion. We must recognise that these fractures can be highly unstable and require prompt and proper immobilisation. Skeletal traction may be used. We caution, however, as do Ackerman (1972), Osgood et al. (1973, I975), Woodruff and Dewing (1963) and Lemmen and Laing (1959), that the traction must be aligned with the existing kyphos. These fractures are mostly extension injuries. If immobilised in extension, further neurological damage, and even death, can occur (Fig. I). Particular care should be given to maintaining alignment during radiography and surgery. As has been previously pointed out by Osgood et al. (1975) and Woodruff and Dewing (1963), these are 'long bone' fractures. Excessive traction will cause separation of the fractured segments. This places undue tension on the spinal cord and vertebral arteries possibly resulting in neurological loss or death. Less than perfect anatomical alignment should be accepted if reduction is not easily achieved.

Early mobilisation of the patient is mandatory if serious medical complications are to be prevented. It is our opinion that the need for good immobilisation of the vertebral column, combined with the need for early mobilisation of the patient, can best be achieved by use of the halo (Young \& Murphy, 1975; Young \& Thomassen, 1974). The halo permits ready access to the chest and abdomen for essential respiratory procedures. Unless there is marked cervical instability, the vest halo may be used. Freeman (1961), Kuhn and Garrett (1972), Rogers (1957), Nickel et al. (1968) and Stauffer (1975) have advocated use of the halo. We share with Osgood et al. (1973, 1975) the firm opinion that the halo is the best method of

\section{immobilize in alignment with existing kyphos}
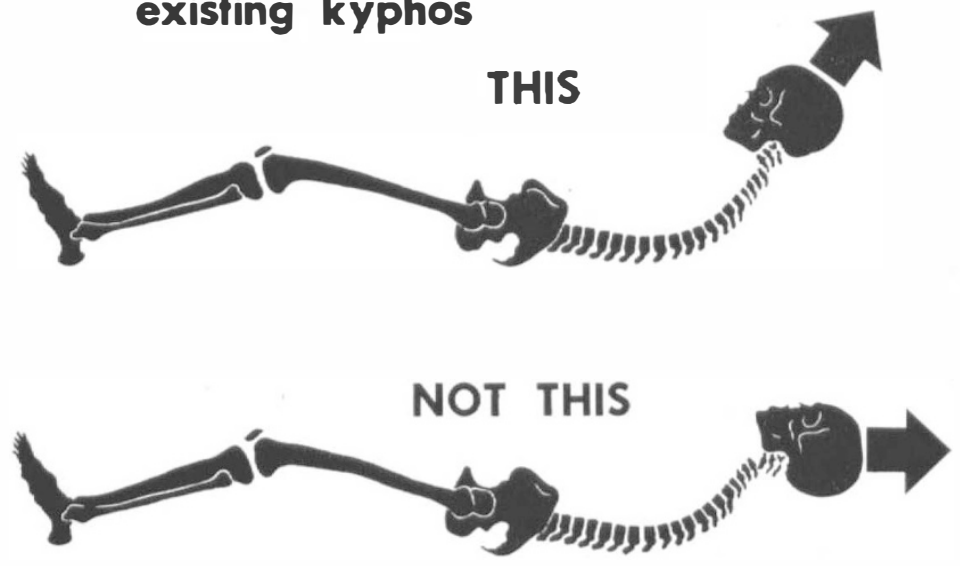

FIG. I 
external fixation for the fractured spondylitic spine. Internal fixation is seldom indicated and is fraught with the surgical hazards associated with these high-risk patients. Further, there is a high likelihood of failure due to the osteoporosis of the ankylosed spine. The one positive and redeeming feature in this group of patients is that they are prone to early bony consolidation and fusion (Ackerman, 1972; Bergmann, 1949; Cheshire, 1969; Good, 1967, Grisolia et al., 1967; Guttmann, 1966; Rand \& Stern, I96I).

Early and intensive respiratory management is essential. This must be provided by a respiratory therapy team working in close co-ordination with the nursing staff, to keep the bronchial tree free of mucous and to provide proper ventilation. Respiratory management in the spondylitic is complicated by the frequent presence of fibrotic lungs and ankylosed rib cages. Spinal cord injury carries with it the diagnosis of impending ileus. A profound ileus combined with an ankylosed thorax can quickly summate into a clinical crisis. The literature does not adequately emphasise the importance of an integrated, intensive programme of respiratory care in these patients. All medical and surgical decisions must consider the extent to which the decision compromises or complicates respiratory management.

\section{Prevention}

Persons with cervical ankylosis commonly suffer low velocity injuries particularly in the spondylitic group. Our colleagues in rheumatology, internal medicine and general practice should be alerted to this potentiality (Osgood et al., 1975). They should caution and instruct their patients to observe such preventive measures as having night-lights in the bedroom, bathroom and dimly lit halls. Handrails should be available in the tub and shower. Persons with cervical ankylosis should be instructed to use handrails when ascending or descending stairs. All should conscientiously use seat belts when riding in an automobile. Above all, they should report all incidences of head and neck trauma to their physician and limit cervical motion until they can be properly examined by their physician. The initial attending physician should take care to obtain cervical films, paying particular attention to protecting vertebral alignment in the process. Such simple measures would significantly reduce the incidence of spinal cord injury in this susceptible group.

\section{Case History}

An illustration of some of the principles presented by this paper is described. The patient was a male, age 68, who fell in a dark room on 17 November 1974, hitting his forehead on a table. He had no initial neurological loss. He did have pain in the posterior aspect of his neck and shoulders. He went to bed and remained there for the next 4 days except for trips to the bathroom and to the dining-room. During the 3 rd and 4th day following injury, he began having weakness and paresthesias in both upper extremities. He was seen in a hospital emergency room by his physician and promptly transferred to our System. On presentation, he had minimal weakness and sensory impairment in the $\mathrm{C}^{-}-\mathrm{C}_{7}$ distributions bilaterally. There were no long tract signs demonstrable in the lower extremities. Bladder function was normal. He was placed in skeletal traction ( $\mathrm{I} \circ \mathrm{lb}$ ) in the best possible alignment. X-rays taken 26 November 1974 remained unchanged from those taken on admission (Fig. 2).

During the first 2 weeks following admission, there was progression of weakness and sensory loss in his upper extremities. Ominously, toward the end of the 2nd week, weakness appeared in his right lower extremity along with sensory impairment in the left 
lower extremity. The reflexes in the lower extremities became hyperactive with bilateral up-going toes. There was loss of bladder function.

Along with these neurological changes, the patient developed pulmonary congestion, pneumonia, atrial fibrillation, dysphagia (Gohel et al., 1976) with impairment of alimen-

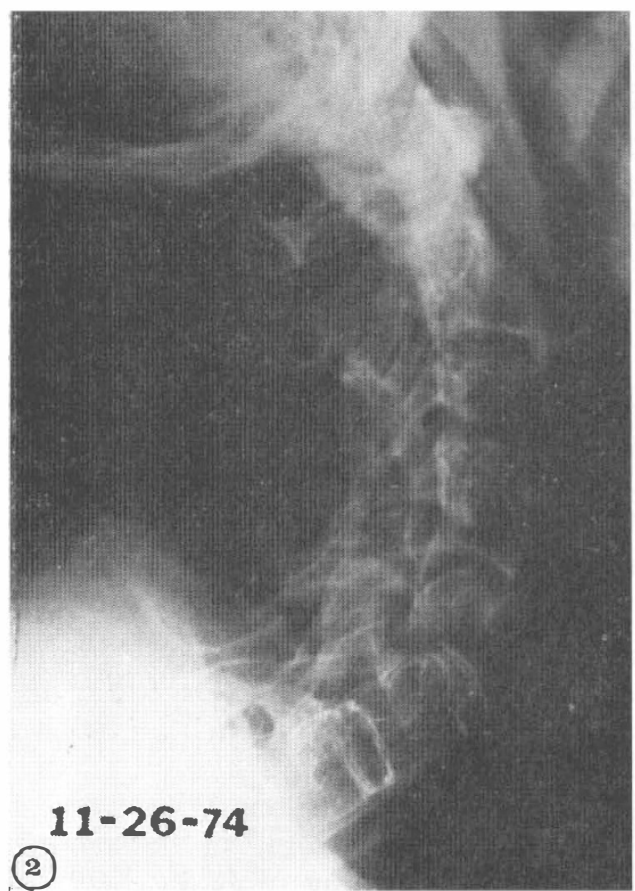

FIG. 2

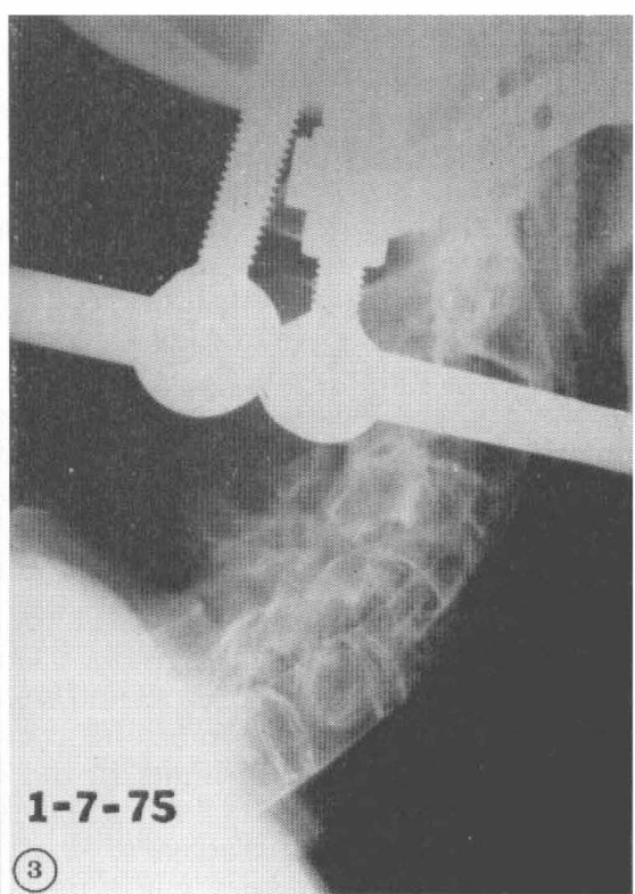

FIG. 3

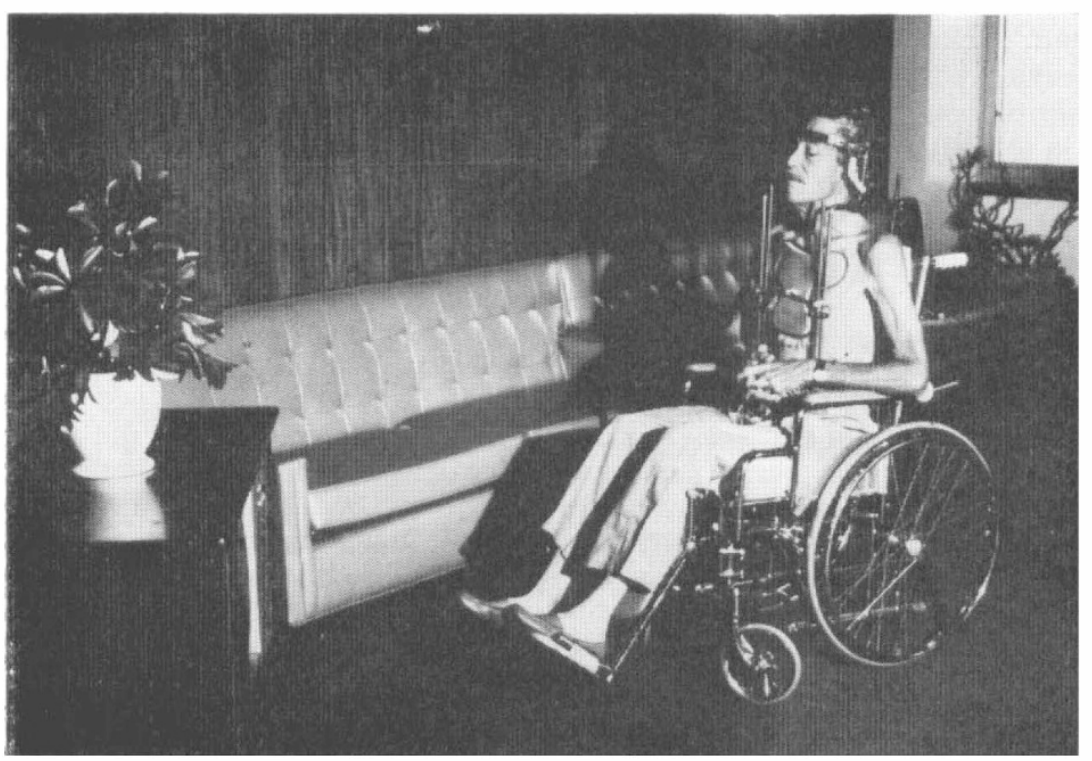

FIG. 4 


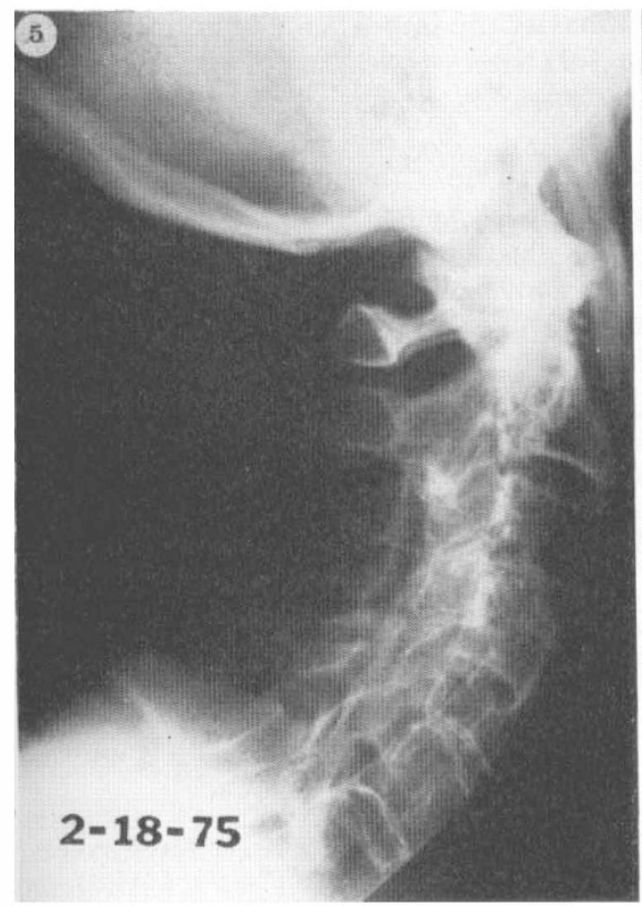

FIG. 5

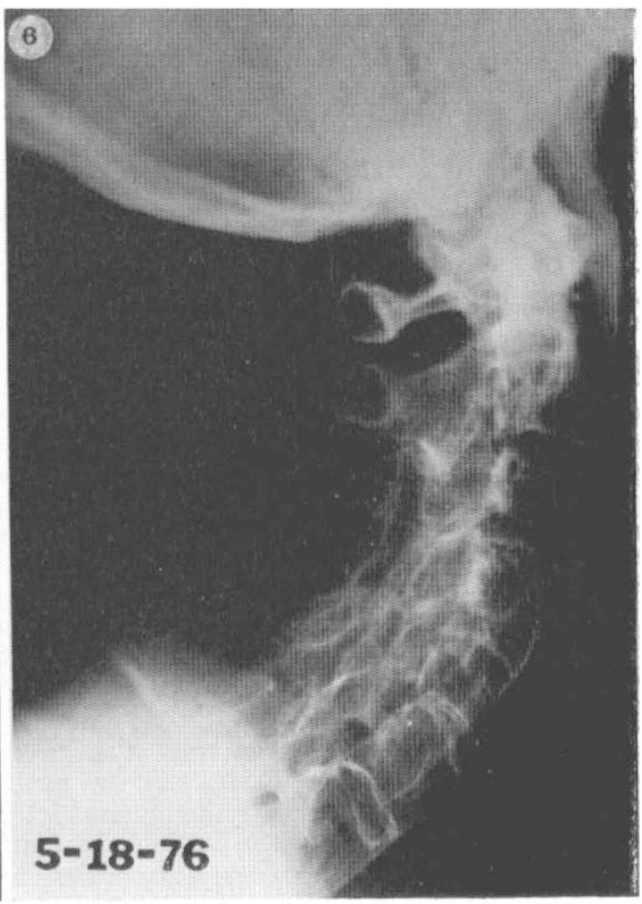

FIG. 6

tation, and marked cerebral disorientation and confusion. Obviously, we were faced with the probability of a paralysed patient, a dead patient, or both. Approximately 3 weeks from injury, the tongs were discontinued and a halo applied (Fig. 3). Within I week there was marked improvement in the patient's medical and neurological status. He was up in a wheelchair for the better part of the day and ambulatory in the therapy gymnasium (Fig. 4). He was discharged to his home, ambulatory within I month in his halo. His cervical spine became stable within 13 weeks following injury, permitting removal of the halo (Fig. 5). Re-examination 18 months following injury showed remarkable consolidation of his spinal injury (Fig. 6). His only permanent neurological deficit consisted of a small area of anaesthesia on the lateral aspect of the right thumb. $\mathrm{He}$ is well and active to this day. An incidental benefit of the entire experience was the improvement in his functional cervical alignment as a result of his traumatic osteotomy. This is not recommended as a treatment of choice.

\section{SUMMARY}

Twenty-three cases of cervical ankylosis with acute spinal cord injury were treated in the Southwest Regional System for Treatment of Spinal Injury between I June 1970 and 3I December 1975. The sub-groups ankylosing spondylitis and degenerative spondylosis share unique characteristics requiring special clinical attention. The sub-group, congenital fusion, had no characteristics at apparent variance with our total spinal cord injury group. The ankylosing spondylitic group presented problems in diagnosis, immobilisation of the fracture and management of medical complications, primarily cardiopulmonary. The basic principle of the clinical management of these elderly people is immobilisation of the fracture and mobilisation of the patient. The halo is the technique of choice for immobilisation of the fracture. 
The literature does not adequately emphasise the importance of an integrated, intensive programme of respiratory care for these patients. All medical and surgical decisions must consider the extent to which the decisions compromise or complicate respiratory management.

Persons with ankylosed spines, particularly those with ankylosing spondylitis, should be educated in the techniques to prevent fractures of their rigid spines.

\section{RÉSUMÉ}

Vingt-trois cas d'ankylose cervicale avec blessure aiguë au cordon médulaire ont reçu des soins au Système Régional du Sud-Ouest pour le Traitement des Blessures Spinales pendant la période Ier juin 1970 jusqu'au 3I décembre 1975. Les sous-groupes, spondylite ankylosante et spondylose dégénérative partagent des caractéristiques spéciales qui exigent un entretien clinique particulier. Le sous-groupe, la fusion congénitale, n'avait pas de caractéristiques en désaccord évident avec notre groupe total affligé de blessures au cordon médulaire. Le groupe spondylitique ankylosant a présenté des problèmes en ce qui concerne la diagnose, l'immobilisation de la fracture, et le traitement des complications médicales, principalement cardio-pulmonaires. Le principe fondamental du traitement clinique de ces gens âgés consiste en l'immobilisation de la fracture et la mobilisation du malade. L'appareil auréolaire ('halo') est la technique préférée de l'immobilisation de la fracture.

Les écrits traitant de ce sujet n'accentuent pas suffisamment l'importance d'un programme intégré et intensif des soins des problèmes respiratoires de ces malades.

En arrivant à toutes décisions médicales et chirurgicales, il faut considérer à quel point ces décisions compromettent ou compliquent le traitement de ces problèmes respiratoires.

Les affligés de colonnes vertébrales ankylosées, particulièrement ceux atteints de spondylite ankylosante doivent être instruits dans la technique d'éviter les fractures de leurs colonnes vertébrales rigides.

\section{ZUSAMMENFASSUNG}

23 Fälle von akutem Halsmark Trauma in Personan mit cervikaler Ankylose werden beschrieben. Gewisse Besonderheiten der grösseren Untergrappen werden erwähnt: Spondylitis ankylopoetica, degenerative Ankylose und kongenitale Fusion. Der Spondylitis ankylopoetica hat eine schlechte Prognose (50\% Mortalität in 60 Tagen), auch hinsichtlich des Verlustes neurologischer Funktion. 5 von 8 Fällen hatten dauernden Verlust.

Das Prinzip der Behandlung ist Immobilisation von Frakturen und die Mobilisierung der Patienten. Der 'Heiligenschein' ist die Methode der Wahl für die Mobilisation von Frakturen. Eine intensive respiratorische Behandlung ist wichtig.

Acknowledgements. Grateful appreciation is extended to members of the medical staffs of St Joseph's Hospital and Medical Center and Good Samaritan Hospital for permission to report data pertaining to their cases.

\section{REFERENCES}

ABDI, O. (1904). Ueber einen Fall von chronischer Arthritis ankylopoetica der Wirbelsaule; Fraktur der Wirbelsaule und Quetschung der Cauda equina. Mitt a d Hamb Staatskrankenanst, Hamb. 4, 57-74. In Good, A. E. (I967).

ACKerman, E. A. (1972). Cervical traction in flexion. A method of maintaining constant angle prone or supine. F. Bone foint Surg. 54A, I I I4-I I I6.

Ankylosing spondylitis may be much commoner than many believe. (1975). F.A.M.A. 233, 495-496.

Barnes, R. (I96I). Paraplegia in cervical spine injuries. Proc. R. Soc. Med., 54, 365-367.

BELL, C. (1824). Exposition of the Natural System of the Nerves of the Human Body, Spottiswoode, London. In Heathfield, K. (1973).

Bergmann, E. W. (1949). Fractures of the ankylosed spine. F. Bone foint Surg. 3IA, 669-67I. 
Brain, L. \& Wilkinson, M. (Eds.) (I967). Cervical Spondylosis, Wllliam Heinemann, London.

Brown, M. W., Templeton, A. W. \& Hodges, F. J. (1964). The incidence of acquired and congenital fusions in the cervical spine. Am. F. Roentgenol. Radium Ther. Nucl. Med. 92, I255-I259.

Burke, D. C. (I97I). Hyperextension injuries of the spine. F. Bone Foint Surg. 53B, 3-I2.

CALIN, A. \& FRIES, J. F. (I975). Striking prevalence of ankylosing spondylitis in 'healthy' W27 positive males and females. N. Engl. f. Med. 293, 835-839.

Cheshire, D. J. E. (I969). The stability of the cervical spine following the conservative treatment of fractures and fracture-dislocations. Paraplegia, 7, 193-203.

FARHAT, S. M., SChNeIder, R. C. \& GRAY, J. M. (1973). Traumatic spinal extradural hematoma associated with cervical fractures in rheumatoid spondylitis. F. Trauma, 13, $591-599$.

FREEMAN, G. E., JR (I96I). Correction of severe deformity of the cervical spine in ankylosing spondylitis with the halo device. F. Bone foint Surg. 43A, 547-552.

Gohel, V. K., Karasick, S. \& Canino, C. (1976). Cervical spondylotic dysphagia. F.A.M.A. 235, 935-936.

Good, A. E. (1967). Nontraumatic fracture of the thoracic spine in ankylosing spondylitis. Arthritis Rheum. 10, 467-469.

Gray, S. W., Romaine, C. B. \& Skandalakis, J. E. (I964). Congenital fusion of the cervical vertebrae. Surg. Gynecol. Obstet. 118, 373-385.

Grisolia, A., Bell, R. L. \& Peltier, L. F. (1967). Fractures and dislocations of the spine complicating ankylosing spondylitis. F. Bone foint Surg. 49A, 339-344, 386.

GutTMANN, L. (1966). Traumatic paraplegia and tetraplegia in ankylosing spondylitis. Paraplegia, 4, I88-203.

Hansen, S. T., Taylor, T. K. F., Honet, J. C. \& Lewis, F. R. (I967). Fracturedislocations of the ankylosed thoracic spine in rheumatoid spondylitis. F. Trauma, 7, 827-837.

Heathfield, K. (1973). Neurological complications of the rheumatic diseases. Rheumatol. Rehabil. 12, 2-21.

Hollin, S. A., Gross, S. W. \& Levin, P. (1965). Fracture of the cervical spine in patients with rheumatoid spondylitis. Am. Surg. 31, 532-536.

Hughes, J. T. \& BRownell, B. (I963). Spinal-cord damage from hyperextension injury in cervical spondylosis. Lancet, $\mathbf{i}, 687-690$.

Janda, W. E., Kelly, P. J., Rhoton, A. L. \& Layton, D. D. (I968). Fracture-dislocation of the cervical part of the spinal column in patients with ankylosing spondylitis. Mayo Clin. Proc. 43, 7I 4-72 I.

Kanefield, D. G., Mullins, B. P., Freehafer, A. A., Furey, J. G., Horenstein, S. \& Chamberlin, W. B. (I969). Destructive lesions of the spine in rheumatoid ankylosing spondylitis. F. Bone foint Surg. 5IA, I369-1 375.

Kewalramani, L., Taylor, R. G., Albrand, D. W. (I975). Cervical spine injury in patients with ankylosing spondylitis. F. Trauma, 15, 93 I-934.

KuHN, R. A. \& GARRETT, A. (1972). The halo in the management of cervical spine lesions. Orthop. Rev. I, 25-27.

Lemmen, L. J. \& Laing, P. G. (I959). Fracture of the cervical spine in patients with rheumatoid arthritis. F. Neurosurg. 16, 542-550.

Lieberg, O. U., SpengleR, D. M. \& BAILY, R. W. (I975). Two-level disruption of the ankylosed spine: a case report. f. Trauma, 15, I064-I066.

Meszaros, G. (I965). Personal communication of 1976 citing his unpublished paper presented at the Canadian Orthopaedic Association Meeting, Halifax, I965.

Nickel, V. L., Perry, J., Garrett, A. \& Heppenstall, M. (I968). The halo: a spinal skeletal traction fixation device. F. Bone foint Surg. 50A, I 400-I 409.

NorthField, D. W. C. \& Osmond-Clarke, H. (1967). Surgical treatment. In Brain, L. and Wilkinson, M., eds. (1967), pp. 207-222.

NuRICK, S. (1972). The pathogenesis of the spinal cord disorder associated with cervical spondylosis. Brain, 95, 87-100.

Osgood, C. P., Abbasy, M. \& Mathews, T. (1975). Multiple spine fractures in ankylosing spondylitis. F. Trauma, 15, I63-166.

Osgood, C., Martin, L. G. \& Ackerman, E. (I973). Fracture-dislocation of the cervical spine with ankylosing spondylitis. F. Neurosurg. 39, 764-769.

Payne, E. E. \& SPIllane, J. D. (I957). The cervical spine; a anatomico-pathological study 
of 70 specimens (using a special technique) with particular reference to the problem of cervical spondylosis. Brain, 80, 57 I-596.

Prolo, D. J., Runnels, J. B. \& Jameson, R. M. (I973). The injured cervical spine: immediate and long-term immobilization with the halo. F.A.M.A. 224, 591-594.

RAND, R. W. \& STERN, W. E. (I96I). Cervical fractures of the ankylosed rheumatoid spine. Neurochirugia, 4, I37-I48.

REINHOLD, H. \& SAUERBREY, R. (I959). Beitrag Zur Angeborenen Blockwirbelbildung und Zur Schipperdrankheit der Halswirbelsaule. Fortschr Rontgenstr Nuklearmed, 9I, 643-648. In Meszaros, G. (1976).

ROGERS, W. A. (I957). Fractures and dislocations of the cervical spine; an end-result study. F. Bone foint Surg. 39A, 341-376.

SCHNEIDER, R. C., Cherry, G. \& PANTEK, H. (I954). The syndrome of acute central cervical spinal cord injury. F. Neurosurg. 2, 546-577.

Shands, A. R., JR. \& Bundens, W. D. (I956). Congenital deformities of the spine; an analysis of the roentgenograms of 700 children. Bull. Hosp. Foint Dis. 17, I IO-I 33.

STAUFFER, E. S. (I 975). Fractures and dislocations of the spine. In Rockwood, C. A. and Green, D. P., Fractures, pp. 835-839, Lippincott, Philadelphia.

Stiasny, H. (1933). Fraktur der Halswirbelsaule bei Spondylarthritis ankylopoetica (Bechterew). Zentralbl. Chir. 6o, 998-100I. In Bergmann, E. W. (1949).

Symonds, C. P. (1953). The interrelation of trauma and cervical spondylosis in compression of the cervical cord. Lancet, $\mathbf{i}, 45 \mathrm{I}-457$.

TAYloR, A. R. (I95I). The mechanism of injury to the spinal cord in the neck without damage to the vertebral column. F. Bone foint Surg. 33B, 543-547.

TAYLOR, A. R. (I953). Mechanism and treatment of spinal-cord disorders associated with cervical spondylosis. Lancet, i, 717-720.

TAYlor, A. R. \& BlACKwood, W. (I948). Paraplegia in hyperextension cervical injuries with normal radiographic appearances. F. Bone foint Surg. 3oB, 245-248.

Weiss, L. S. \& Freehafer, A. A. (I964). Atraumatic subluxation and dislocation of the cervical spine in rheumatoid arthritis. Clin. Orthop. 34, 53-61.

WoodRufF, F. P. \& Dewing, S. B. (I963). Fracture of the cervical spine in patients with ankylosing spondylitis. Radiology, 80, I 7-2 I.

YounG, R. \& MURPhY, D. J. (1975). Step by step procedure for applying the halo vest. Orthop. Rev. 4, 33-36.

Young, R. \& Thomassen, E. H. (1974). Step by step procedure for applying the halo ring. Orthop. Rev. 3, 62-64. In Young, R. and Murphy, D. J. (1975). 